\title{
Pathology of Social Accountability in Civil Society: Cultural Commodification
}

\author{
Rutiana Dwi Wahyunengseh \\ Regional Development Information Center, \\ LPPM Universitas Sebelas Maret \\ Surakarta, Indonesia \\ rutiana.dwi@staff.uns.ac.id
}

\author{
Sri Hastjarjo \\ Departement of Communication Science, \\ Universitas Sebelas Maret University \\ Surakarta, Indonesia \\ sri.hastjarjo@staff.uns.ac.id
}

\begin{abstract}
Democratic governance is adhered to the basic assumption that democracy upright through the involvement of civil society. Accountability perspective view civil society as a major actor enforcement role to uphold democratic values of equality, openness, fairness. A case study in the city of Surakarta showed pathological symptoms of civil society's role in social accountability mechanisms are contradictory to the values of democracy, namely the cultural commodification, thereby triggering other pathological forms: patronage, clientelism, citizens voice commoditization, and incivility. Cultural commodification weaken demand driven of social accountability. Required study Theory of Change to reduce cultural commodification.
\end{abstract}

Keywords-Pathologhies, Social accountability, Civil society, Comodification Culture, democracy,

\section{INTRODUCTION}

Civil society plays a very important position in democratic governance. Democratic governance contains basic assumption of democracy related to power sharing, the balance of power between state and the involvement of civil society. One of strategic roles the civil society play is to encourage social accountability in the management practice and public policy. The balance of power is the important component to build social accountability. Social accountability is the important issue under democratic governance to improve the quality of governance. The function of social accountability is to supervise political officials or bureaucrats in policy issue, policy development process, or service function implementation [1].

Democratic governance raises a question "how does the society organize itself to get equal access and just treatment socially and economically for every citizen?" [2]. Reference [3] stated that democratic governance is characterized with eligible people in a polity participate actively not only in determining the kind of people that govern them, but also participate actively in shaping the policy output of government. Reference [4] stated that democratic governance is characterized with the everyday rights, interests, perspectives and involvement of civil society at large [are] taken into consideration by the powers - that -be, in between elections. So, the dynamic role of civil society in democratic governance is to create bargaining power with the government and finally local organized democratic groups [5].

\section{METHODS}

This research employed case study with phenomenological focus, using constructivism paradigm in interpretive perspective, analyzing the phenomenon of actor's behaviour and its point of view in the practice of civil society activist in social accountability forum held in Surakarta and Magelang Cities, Central Java Province, Indonesia. From this constructivism interpretive perspective, it can be studied the contextual aspects that lead to biased actor behaviour from social accountability normative theory. The framework of pathological analysis, the negative characteristics affecting the achievement of social accountability substantive's substantive objective, used in this study was social accountability pathology from civil society activist side, emerging in its relation to government in the mechanism of social accountability democratization. The framework of civil society pathology is categorized into: patronage, clientele, and citizen voice commodification [6]. Research triangulation used was research informant triangulation by asking the same question subject to different informants, and data collection technique triangulation, in which the topic was explored in three ways: in-depth interview, field observation, and document analysis. The case group as the research object included (i) special interaction forum of government and society fulfilling the criterion of accountability forum, and (ii) forum initiated by $\mathrm{NGO}$ or citizen related to public issue advocacy. Meanwhile, the group becoming the subject of research analysis was civil society, including NGO, citizen forum activist, citizen activist, and local media actor. The group becoming the complement subject of research to build the meaning interpretation setting of civil society's role was explored from its relation partners: local government element and Local Legislative Assembly element.

\section{RESULTS AND DISCUSSION}

\section{A. Roadmap of Social Accountability and Sacred Role of Civil Society}

The shift of accountability mode toward social accountability develops along with the shift of government to governance concept, the discourse "to bring the public back" 
as the primary target of accountability. Social accountability approach emerges as a response to accountability deficit, both vertical and horizontal accountability in new public management era, the bias of beneficiary to the elite group despite democratically packaged process. Accountability deficit means that accountability does not function well so that some condition attenuating accountability results. Accountability deficit results from some aspect inherent to bureaucracy and democratic system, including (i) putting political institution and government institution as the public accountability monopoly holder; (ii) the rigid formal accountability mechanism; (iii) the opportunistic and collusion potential between public institutions [7]. The social accountability approach builds on an idea of community empowerment and human right-based approach to development. The concept of social accountability lies on the frame of democratic rights and obligation. Social accountability is believed as completing formal accountability mechanism and reinforcing more the democratic element based on citizen voice [8][9][10][11].

Social accountability aims to encourage the formulation of public-mandated values into the rule held on and followed by the public officials in practice. Social accountability is in hybrid form, working in the existing formal accountability system and reinforcing the horizontal accountability system to make the vertical accountability effective [12]. The citizen group's active action attempt to implement this public accountability called as informal institutions of accountability because the citizens do not have legal formal authority as the accountee [13]. The social accountability mechanism can be initiated by civil society or along with the government and other actor [14][15][16]. Social accountability is also called as society driven horizontal accountability to obtain direct answer from government and people's representative in the parliament as the formal accountability holder [17][18].

Normatively, civil society group is the inter-actor community network driven to struggle for mutual interest as the citizen. They should hold anti-violence and anti-repressive value orders, restrict themselves with plurality value system, struggle for diverse mutual interest, and have strategy to embrace all components of citizen without discrimination. Civil society group can be in the form of association, foundation, NGO, solidarity network, paguyuban (association), care group, and society group [19]. Civil society is exalted as the group that can prevent bureaucratic disease through control it plays, requiring social accountability[20]. Diversity and density of society group is democratic supervisor and ensure that the result of public decision making process is viewed and tested from various different perspectives.

\section{B. Agency Theory and Civil Society Pathology}

Agency theory or theory of agency explains the relation between agent and principal of its incentive and institutional structures [21]. Agency theory builds on three following assumptions. (a) Assumption about human characteristics: selfish, having limited rationality, and not liking risk. (b) Assumption of organization: conflict between organization members, efficiency, and information asymmetry between principal and agent. (c) Assumption about information: information is considered as a tradable commodity. Agency theory explains that the principal-agent relation is potentially problematic, potentially creating moral hazard and opportunistic behavior constituting normative deviation. Moral hazard is the problem arising if the agent does not do what has been agreed with principal (normative). Furthermore, opportunistic behavior is the utilization of resource and access owned for personal or group interest. The agent's opportunistic behavior occurs because it has more information than the principal does (information asymmetry). Meanwhile, the principal's opportunistic behavior occurs because it has advantage in certain power affecting the agent [21][22] Information asymmetry is the fundamental problem in the agent-principal relation. Agency theory proposes that every individual has its own personal interest thereby will have conflict of interest every time they attempt to be involved in cooperative effort [23].

In the context of social accountability, civil society or society forum representative becomes agent for the society it represents. Agency theory is used in this research to explain the problem of relation between accounted and accounted, information asymmetry dynamic, and incentive link triggering the actor's behavior in social accountability room. Basic assumption about the problem of accountor-accountee relation is used in agency theory, including self interest, information asymmetry/information transparency, and opportunistic behavior, used to explain the forms of pathology emerging in social accountability mechanism of local budgeting.

Meanwhile, the problem of civil society's role in social accountability is traced to social accountability variable consisting of: (i) government's political will to involve the society, (ii) capability of society member group organization, (iii) information transparency variable, and (iv) environment context variable [9][24][25][26][27]. Pathological metaphor used in the study of public administration science to explain various pathologies leading to dysfunction, for example: bureaucratic pathology [20] and democratic pathology [28][29][30]. Analysis on bureaucratic and democratic pathologies is used because the structure of social accountability occurs in the context of relation to bureaucracy and society interrelation in the practice building on democratic principle. Interrelationship between government element/political officials and society with bureaucratic structure and democratic practice in local environment presumably has the opportunity of resulting in pathology of social accountability [5][6][31][32][33][34][35][36][37][38].

Pathology of social accountability can be defined as a variety of symptoms leading to dysfunction of social accountability mechanism or a condition disrupting the functioning of social accountability system substantively. Social accountability dysfunction is counterproductive to 
democratic values. Social accountability is normatively believed as reinforcing democratic values such as justice, equal access, and anticorruption [39].

Certain civil society group can be antidemocratic, the one promoting fanaticism, clientele, and tending to ignore diversity and difference of other groups thereby harmful to mutual interest value reciprocally [37]. The relation between civil societies is not always in line with consensus. The society groups with different perspective, interest and agenda are adjacent and competing each other in the same scope to win control and effect on the rule holder. The character of dynamic relationship between both of them is highly determined by power interest and can change in any time [19]. Refrence [20] stated that Non-government organization and civil group can be contaminated in paternalistic society culture and less democratic political system. As a result, the capacity of media, NGO, and other civil groups becomes weak, thereby reducing the growth of bureaucratic pathology. Although civil society capacity reinforcing movement is conducted to control bureaucracy, it cannot reduce the risk of bureaucratic dysfunction. The role of civil society is often hindered by the behavior of civil society activists acting to get personal benefit thereby lowering the society's trust.

\section{Pathology of Social Accountability in Civil Society}

The participation of civil society in the context of budgeting planning process in Surakarta and Magelang City results in paradox of inclusion versus elitist. Those that can enter into citizen forum tend to have special legitimacy, for example, mastering information, becoming the chairperson of organization or citizen association enlisted in the government, having symbol of society figure, having mass power under their control, and other elitist power. The citizen with such the attribute tends to be embraced by government on the behalf of public engagement.

Instead, the procedure of fulfilling the inclusive element results in elitist compartments among the citizens. There are some elitist groups in the citizens. Firstly, it is elitist group due to a close relationship to government structure, for example: RT/RW (neighborhood association/citizens associations). Secondly, it is elitist group due to capital domination, for example: employer/business performer association. Some elitist group is due to science, such as academician. Next, it is elitist group due to massive adherent power, for example: society leader, religious leader, citizen forum group leader, NGO activist, chairman of association or mass organization and similar. Finally, it is these elitist groups that dominate the representative room of citizen forum. Thus, inclusiveness element results in paradox of elitist and dominative.

The effect of public representativeness attribute results in the dynamic negotiation of public budgeting decision containing the competition of society group powers. Elitist and dominative citizen forums will harm the dysfunction of balance between budget allocation priority and even development distribution agenda. The domination of group that is more vocal and has supportability tends to get more budget allocation despite no priority. For example, the rich kelurahan (administrative village) will have better physical environment and infrastructure because it has the strong representative in budgeting process. Meanwhile, priority element and event distribution element should be maintained for its balance to reduce the risk of conflict between groups. Priority element promotes partiality to certain group because of rational deliberation. Meanwhile, distribution element promotes the attempt of mitigating the conflict by distributing the existing resource evenly to all groups.

The paradox of inclusiveness-elitist can also be seen in the rule holder's tendency to involve the citizen representative of the group securing its policy. For example, Paguyuban Pedagang Kaki Lima (Street Vendor Association) enlisted in city government will get facilities, while the one not recognized will be treated differently. City government will consider that the arrangement of Street Vendor it implements has been democratic if measure from the assessment of the pro-government association groups. This phenomenon indicates partial accountability pathology or clientele tending to benefit the pro-ruler group.

The society representative groups sometimes work based on consensus and informal ways, for example through mediation by informal figures, lobbyist, and NGO. So the demand-driven social accountability forum of citizen tends to result in citizen forum commodification and incivility action (psychological or physical violence) against other citizen groups having interest contestation. Their position as the public representative results in the effect of proximity to the ruler thereby making the representative/mediator feeling important. It tends to feel the need for maintaining its legitimacy source by means of supporting the rule (power). This phenomenon leads the civil society activist to be mediator/bridge/broker of citizen's and government's interest. This pathology solidifies the position of elitist, clientele, and broker counterproductive to the substance of social accountability values including transparency, justice, equal access, and rational responsibility. It is in line with Celina Souze (no year) finding the paradox of authentic participation in Brazil. The intended paradox of authentic participation is the deviation of participation mechanism tending to change the leaders of civil society and institution into the broker of political interest not based on the society's need. Consequently, social accountability is oriented to fulfill the legitimacy of public broker group only.

Some forms of pathologies are found in civil society as accountee in social accountability mechanism: (i) group/forum commodification; (ii) elitist or dominative; (iii) incivility. Group/forum commodification is to use citizen group in the attempt of project sustainability or to give personal or group benefit. Group/forum commodification can be seen from the presence of the conflict of relationship between civil society groups or between civil society and government. Group commodification can also be seen from the phenomenon of case of interest transaction between civil society and ruler holder (government or political officials). Elitist or dominative 
pathology is the presence of more vocal group marginalizing the less vocal group. The presence of incivility behavior, both direct and indirect violence, results in domination or marginalizes other group, thereby harming the mutual interest reciprocally. Incivility means that civil society ignores the elements of discussion, peace, and no violence as the spirit of civil society.

The context of society environment as demand driven is still dependent on external support, such as donor institution. The dominating incentive is economical motive intended to get income. Thus, it vulnerably results in commodification of forum and broker, utilizing the forum for the sake of obtaining extra income. Thus, the forum vulnerably becomes the clients of the rulers and pseudo-forum. Civil society commodification culture is the utilization of citizen voice for the interest of activist group, through transaction with the ruler or to get economic resource. The pathology of commodification culture impacts on

i. misfunction of citizen forum accountee because it will be the proponent and connive with the government and the politicians thereby preserving elite capture and maintaining money-politics culture.

ii. attenuating the citizen's trust in civil society activist and strengthening the citizen's apathy

iii. vulnerability to the dissension between groups because of competition for resource and resulting in domination of the more vocal group, marginalizing the less vocal one.

\section{CONCLUSION}

The result of research increases critical thinking of nearly undoubted assumption in democratic governance that "almost unquestioned assumption that the creation or enhancement of accountability mechanisms of any sort will result in greater democracy" (Dubnick, 2002). This research finds that the qualities of democracy and bureaucracy impacts on the quality of civil society's role in the mechanism of social accountability. If the quality of democracy is proceduraloriented and bureaucracy contains corruption, collusion and nepotism defect, the role of civil society as the leverage of social accountability will be defective as well with cooptation, forum commodification, and incivility. The result is the pseudo-role of civil society for pseudo social accountability. The theoretical finding of the research on the role of civil society in social accountability is formulated in the following proposition "interaction between civil society element and the rule holder occurring in procedural formality culture will result in commodification culture, thereby yielding pseudo social accountability).

For that reason, the recommendation for further research is to apply the Theory of change to study the incentive of citizens participating genuinely and processing their voice thereby having control power over the ruler and the civil society activist on the behalf society representative

\section{ACKNOWLEDGMENT}

The author thanks to Faculty of Social and Political Sciences and Regional Development Information Center, the Institute for Research and Community Services of Sebelas Maret University for supporting given to complete this article publication in this International Conference.

\section{REFERENCES}

[1] C. Malena, R. Forster, and J. Singh, "Social Accountability: An Introduction to Concept and Emerging Practice," in Social Development Papers, Participation and Public Engagement, Paper No. 76, December 2004.

[2] G. Sabhir Cheema, Building Democratic Institutions: Governance Reform in Developing Countries. Westport: Kumarian Press, 2005.

[3] P. S. Reddy, T. Sabelo, "Democratic Decentralization and Central/Provincial/Local Relations in South Africa," in International Journal of Public Sector Management, Vol 10, Iss: 7, 1997, pp.572 588 .

[4] F.K.W. Loh, "Procedural Democracy, Participatory Democracy and Regional Networking: The Multi-terrain Struggle for Democracy in Southeast Asia," in Inter-Asia Cultural Studies, Vol 9, 1, 2008, pp.127-141.

[5] Pratikno and C. Lay, "From Populism to Democratic Polity: Problems and Challenges in Solo, Indonesia," in Democratisation in the Global South: the Importance of Transformative Politics, K. Stokke and O. Tornquist, eds. New York: Palgrave Macmillan, 2013, pp 254-276.

[6] R.D.Wahyunengseh, Patologi Akuntabilitas Sosial (Studi Kasus dalam Proses Perencanaan Penganggaran Daerah di Kota Surakarta dan Kota Magelang). Yogyakarta: Universitas Gadjah Mada, Disertasi program Doktor Manajemen dan Kebijakan Publik. 2016, unpublished.

[7] M.Ungar, "Democracy, Law, and Order," in Latin American Research Review, Vol. 44, Issue 3, USA: Latin American Studies Association 2009, pp. 235-246.

[8] P. Newell and J. Wheeler, Rights, Resources and the Politics of Accountability. London: Zed Books, 2005.

[9] E. Peruzzotti and C. Smulovitz, Enforcing the Rule of Law: Social Accountability in New Latin American Democracies. Pittsburgh: University of Pittsburgh Press, 2006.

[10] A. Joshi, "Producing Social Accountability? The Impact of Service Delivery Reforms," in IDS Bulletin,Vol 38,Issue 6, 2008, pp.10-17.

[11] M.D. Mehta, Encyclopedia of Governance, M. B. Risk, eds. Sage Publication, 2007.

[12] A.M. Goetz and R. Jenkins, "Hybrid Forms of Accountability: Citizen Engagement in Institutions of Public-Sector Oversight in India", in Journal Public Management Review, Vol 3, Issue 3, 2001, pp. 363 383.

[13] L.L. Tsai, Accountability without Democracy. New York: Cambridge University Press. 2007.

[14] J.M. Ackerman, "Social Accountability in the Public Sector: A Conceptual Discussion, " in Social Development Paper vol 82, March. Washington DC, 2005.

[15] T. Erkkila, "Governance and Accountability a Shift in Conceptualisation," in Public Administration Quarterly, Vol. 31, No. 1/2 (SPRING 2007-SUMMER 2007), 2007, pp. 1-38.

[16] M. Clarke and B. Missingham, "Active Citizenship and Social Accountability," in Development in Practice, Vol 19, issue 8. Taylor \& Francis, 2009, pp. 955-963.

[17] R. Stapenhurst and M.O'Brien, "Accountability in Governance," World Bank PREM Note No 4. Washington DC: The World Bank, 2008.

[18] A.A. Adesopo, "Inventing Participatory Planning and Budgeting for Participatory Local Governance in Nigeria," in International Journal of Business and Social Science, Vol 2, Issue 7, 2011.

[19] A. Akman, "Beyond the Objectivist Conception of Civil Society: Social Actors, Civility and Self-Limitation," in Political Studies Association, Volume 60, Issue 2, 2012, pp.321-340. 
[20] A. Dwiyanto, Mengembalikan Kepercayaan Publik Melalui Reformasi Birokrasi. Jakarta: PT Gramedia Pustaka Utama, 2011.

[21] B.M. Mitnick, Origin of the Theory of Agency: An Account By One of the Theory's Originators. http://dx.doi.org/10.2139/ssrn.1020378, 2013.

[22] K.Vafaï, "Delegation and Opportunism", in Journal of Institutional and Theoretical Economics (JITE)/Zeitschrift für die gesamte Staatswissenschaft, Vol 160, Issue 3, September, 2004, pp. 498-521,

[23] M..C. Jensen, "Self Interest, Altruism, Incentives, and Agency Theory," in Michael C. Jensen, Foundation of Organizational Strategy. USA: Harvard University, 1998.

[24] M. Björkman and J. Svensson, "Power to the People: Evidence from a Randomized Field Experiment on Community-Based Monitoring in Uganda," in Quarterly Journal of Economics Vol 124, Issue 2, 2009, pp.735-769.

[25] D. Greiling and K. Spraul, K, "Accountability and the Challenges Information Disclosure," in Public Administration Quarterly, Vol 34, Issue 3 (Fall), 2010, pp.338-377.

[26] ANSA-EAP, "Social Accountability Perspectives and Practices in East Asia and the Pacific," in Social Accountability Stocktaking ReportIndonesia, Manila. Affiliated Network for Social Accountability in East Asia and the Pacific (ANSA-EAP), 2012.

[27] A.J. Fox, "Social Accountability: What Does the Evidence Really Say?, in World Development, Vol 72, 2015, pp.346-361.

[28] Kapp, Silke and A.P. Baltazar, (2012). The Paradox of Participation: a Case Study on Urban Planning in Favelas and a Plea for Autonomy, in Bulletin of Latin American Research. Blackwell Publishing, 2012.

[29] E. Swyngedouw, "Post-Democratic Cities for Whom and for What?, Paper Presented in Concluding Session Regional Studies Association Annual Conference Pecs. Budapest: 26 May 2010.

[30] L.Ennser-Jedenastik, "The Politicization of Regulatory Agencies: Between Partisan Influence and Formal Independence," in Journal of
Public Administration Research and Theory, Vol 6, Issue 3. USA: Oxford University Press 2016, pp.507-518.

[31] J. Koppell, "Pathologies of Accountability," in Public Administration Review, Vol 65, Issue 1, 2005, pp. 94-108.

[32] K.J. Meier and L.J. O'Toole Jr., "Political Control versus Bureaucratic Values: Reframing the Debate," in Public Administration Review, Vol 66, Issue 2, 2006, pp. 177-92.

[33] K. Yang, and K. Callahan, "Citizen Involvement Efforts and Bureaucratic Responsiveness: Participatory Values, Stakeholder Pressures, and Administrative Practicality," in Public Administration Review, Vol 67, Issue 2 (March- April), 2007, pp. 249-264.

[34] H.J. Trenz, "European Civil Society: Between Participation, Representation and Discourse," in Policy and Society, Vol 28, Issue 1, 2009, pp.35-46.

[35] T. Nabatchi, "Addressing the Citizenship and Democratic Deficits: The Potential of Deliberative Democracy for Public Administration," in The American Review of Public Administration Vol 40, Issue 4, 2010, pp. 376-399.

[36] M.J. Dubnick and K.Yang, "The Pursuit of Accountability: Promise, Problems, and Prospects," in The State of Public Administration: Issues, Challenges, and. Opportunities, D.C. Menzel, and H.L. White, eds. NY: M. E. Sharpe, 2011.

[37] H.O. Kondrikova, Struggling for Civility the Idea and the Reality of Civil Society an Interdisciplinary Study with a Focus on Russia. Universal Press: Radboud University Nijmegen, 2012.

[38) K.R. Hendriksen, "Depoliticization and Public Participation: Extending Madsen," in Psychology \& Society, Vol 5, Issue 2, 2013, pp. 58-61.

[39] D.W. Brinkerhoff and A. Wetterberg, "Gauging the Effects of Social Accountability on Services, Governance, and Citizen Empowerment," in Public Administration Review, Vol 76, Issue 2 March/April 2016, pp. 274-286. 